DOI: $10.24136 /$ tren.2020.002

\title{
CONCEPT «SMART FREIGHT WAGON»
}

\author{
Zbigniew Łukasik ${ }^{1}$, Anton Ushakov ${ }^{2 *}$ \\ ${ }^{1}$ Kazimierz Pulaski University of Technology and Humanities in Radom, Faculty of Transport, Electrical Engineering and Computer Science, \\ Malczewskiego 29, 26-600 Radom, Poland, e-mail: z.lukasik@uthrad.pl \\ ${ }^{2}$ Kazimierz Pulaski University of Technology and Humanities in Radom, Faculty of Transport, Electrical Engineering and Computer Science, \\ Malczewskiego 29, 26-600 Radom, Poland, e-mail: ushakov@cheby.net \\ ${ }^{*}$ Corresponding author
}

Reviewed positively: 20.02 .2020

Information about quoting an article:

Łukasik Z., Ushakov A. (2020). Concept «Smart freight wagon». Journal of civil engineering and transport. 2(1), 19-33, ISSN 2658-1698, e-ISSN 2658-2120, DOI: 10.24136/tren.2020.002

Abstract - This article discusses the prospects for the implementation of the concept «Smart freight wagon» on the Russian railways. The article discusses a concept for developing in Russia a system for monitoring the operating conditions of rolling stock and transmitting telemetry data on the state of infrastructure under the design names «Smart freight wagon. Also, authors offer the author's concept of this system improvements based on openHAB smart system model which helps to make the modular system in order to increase fault tolerance and flexibly adapt to the needs of specific customers.

Key words - Russian Railways, «Smart freight wagon», «Smart Locomotive»

JEL Classification - L92

\section{INTRODUCTION}

The question of how to effectively obtain and process data on the condition of containers during railway transportation has been concern to scientists since the last quarter of the 20th century, when satellite navigation technologies appeared and microprocessor technologies gradually appeared and improved.

Currently, with the deployment of wireless broadband Internet access systems based on cellular and satellite networks in most of Eurasia, it has become possible to transmit and receive data on the entire container route, and not just at intermediate points on the route at large stations.

The development of microprocessor and sensor technologies has allowed the creation of autonomous modules the size of a palm or smaller, which for several months or years without recharging are able to collect, process and transmit the necessary data about the state of the container.

The totality of these technologies and devices created on their basis all over the world are called "smart" (for example, "smart home" technologies).

This trend has not been ignored on transport and the world's largest railway infrastructure players are creating their own variations of the technology of smart railways.

At the moment, by the order of Russian Railways, a number of Russian enterprises jointly with the Skolkovo Fund are implementing a concept for developing a system for monitoring the operating conditions of rolling stock and transmitting telemetry data on the state of infrastructure under the design names «Smart freight wagon» and «Smart Locomotive».

Consider the features of this system implementation and offer author's options for its implementation.

\section{I. "SMART FREIGHT WAGON»}

REASONS FOR THE APPEARANCE OF THIS SYSTEM

The need to implement a real-time tracking system for the parameters of freight wagons is long overdue.

So according to the vice-president of the Wagon Builders Association Alexei Sokolov: "Such information will be requested either by the owner of freight wagons, or by the owner of infrastructure, or by the state. For freight wagons owners, for example, the information transmitted will be able to prove the validity of the uncoupling 
for repairs and the origin of the damage. For infrastructure owners, it is important if the "smart wagon" continuously reports on the status of the infrastructure. Such information is extremely valuable, since it allows you to more rationally build a maintenance system for the railway track" [1].

Anna Orlova, Doctor of Technical Sciences, Deputy General Director for Scientific and Technical Development of PJSC UWK "United Wagon Company" that creating the concept of a smart wagon UWK divided the possibilities of using various systems for it into four large areas [2]:

- The first area is monitoring the rolling stock condition (Are there defects on the wheel surface, spring suspension is normal, is there an overload of the rolling stock during loading);

- The second area is the monitoring of the infrastructure technical condition through measurements using systems installed on wagons. Indicators of dynamic qualities are measured, indicators of interaction with the railway track, as a result, sections of the railway track with not very good technical condition are identified, which need to be repaired;

- The third area is monitoring compliance with wagon operating conditions. It is about identifying certain events. For example, whether the wagon was hit with great force in the automatic coupler because it was pulled off the hill at too high a speed or it was hit by a grab at unloading;

- The fourth area is resource control. This is a long-term observation of the operation of the wagon, its dynamic workload as a result of operation, based on which it can be concluded whether the wagon has exhausted its resource or not. Principle of systemic analysis.

\section{IMPLEMENTATION FEATURES OF THIS SYSTEM}

According to the specialists of the Scientific and Technical Center "Ingetrans" the implementation of this system will achieve the following positive indicators [3]:

- Identification of latent faults and defects wil make it possible to quickly carry out repairs and reduce the negative impact on the condition of the railway;

- Registration of dynamic movement indicators and study of the wagon interaction with the railway will help to identify areas that require priority repair;

- Identification of non-compliance events of the wagon operating conditions with standards will allow documenting the facts of improper handling of wagons in relation to time and GPS coordinates;

- Long-term monitoring of the wagon operation and its dynamic loading will make it possible to understand whether it has exhausted its assigned resource.

At the same time, it is not currently possible to describe the specific mechanisms of this system functioning, since it is still in the planning and development stage. So, according to Anna Orlova, Deputy General Director for Scientific and Technical Development of UWK, during the annual conference of the Vedomosti newspaper "Barriers and Growth Points for the Russian Transport Industry: Railway Sector" [4]: "It will take at least three years to create a smart wagon. While the development of such rolling stock rests on the

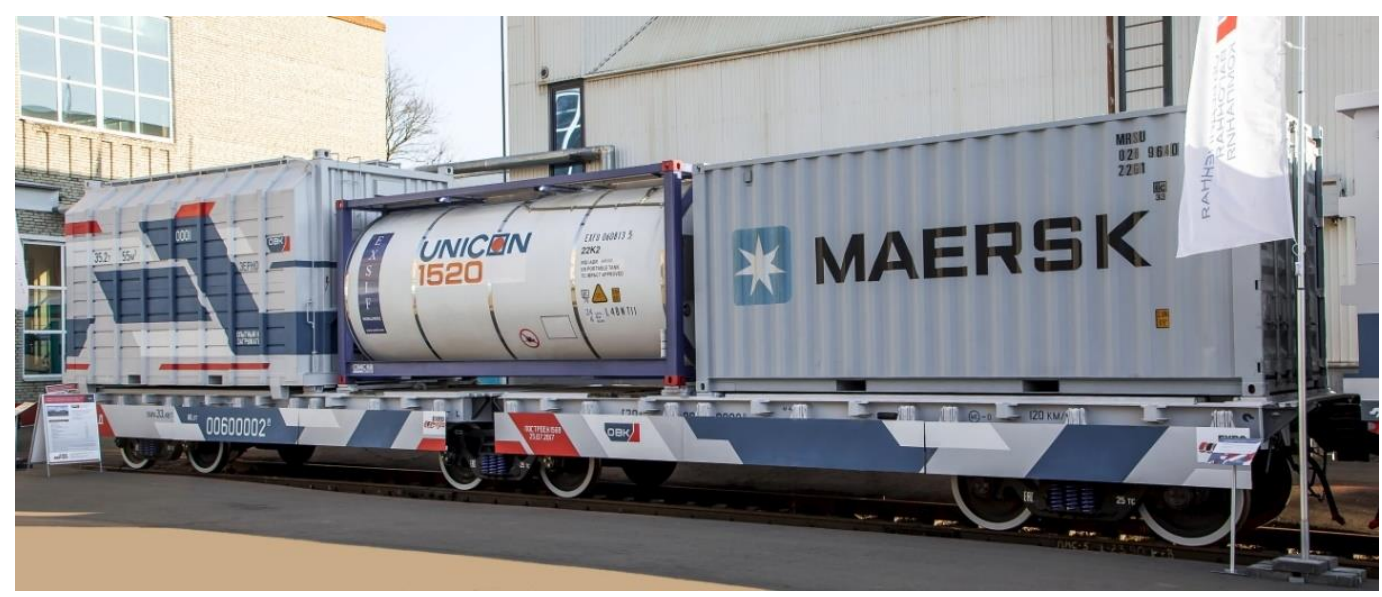

Fig. 1. An exemplary view of a smart freight car [4] 


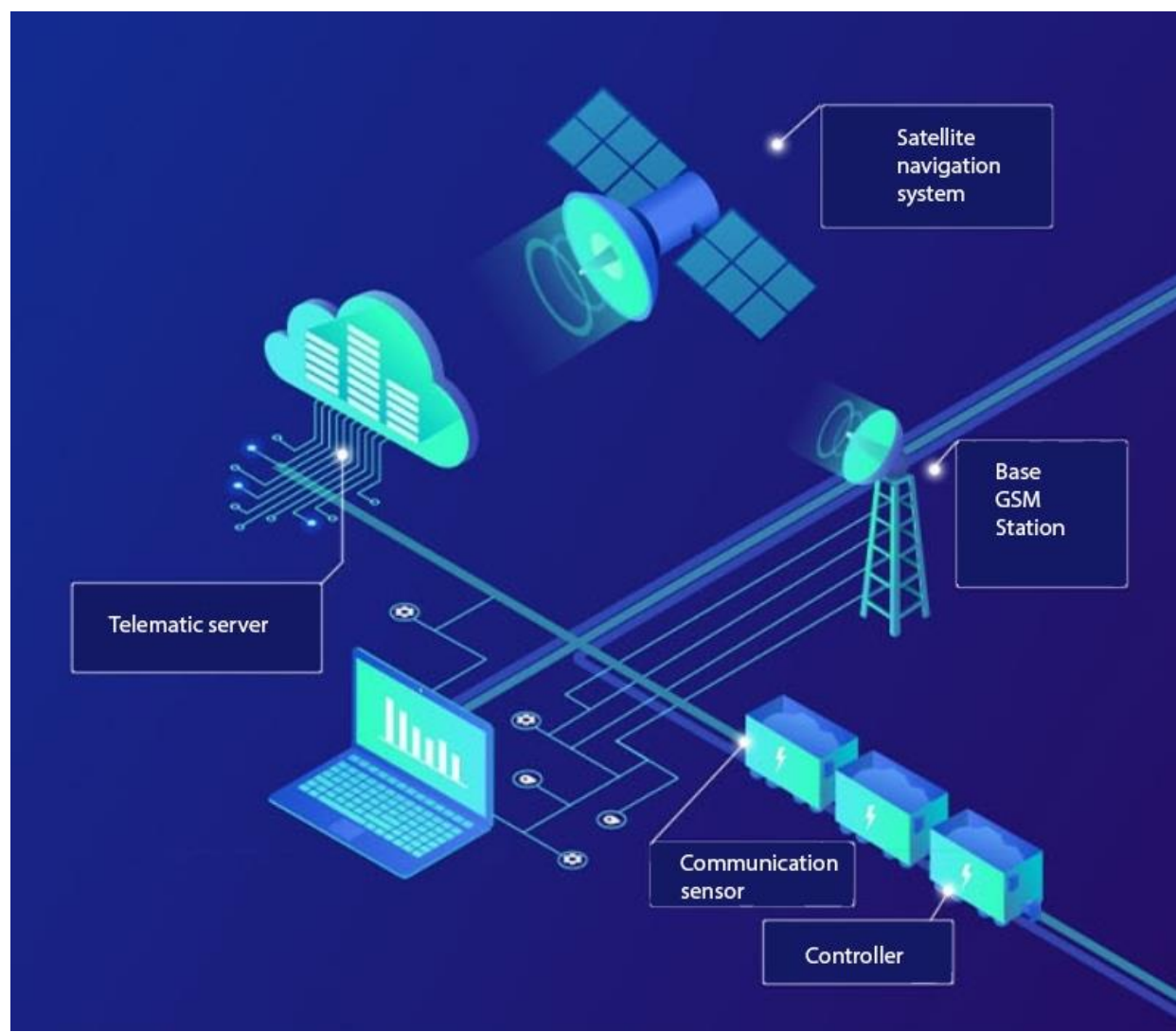

Fig. 2. A general description of this system operation [3]

solution of several technological problems. So, it is necessary to develop an energy source for a freight wagon, as well as an energy-efficient information collection system, taking into account the available capacity. Another task is the transition from the point-based freight wagon registration of noncompliance with the regulatory requirements along the route to a system of continuous and continuous monitoring of changes. In addition, the identification of changes in the wagon with the scenario of its operation will require the creation of a unified system for managing the information received based on Big Data digital technologies".

Currently, freely available information about this system is limited to several renderings of the possible wagons and slides with a general description of this system operation (Fig. 1 and Fig. 2).

As we see, the development of this system is at a very early stage, so the first test samples of "smart wagons" can be seen no earlier than 2021.

\section{ASSESSMENT OF THE NEED FOR THE IMPLEMENTATION} OF THIS SYSTEM BY THE BUSINESS

The largest container transport operators in Russia thinks, that the idea of a "smart wagon" seems interesting, but so far difficult to put into practice.

So the general director of UMMC-Trans LLC Vladimir Tarasenko notes [1] that "First, an understanding of such system cost is necessary. Secondly, it is necessary to have an understanding of the location of this system on train. I think that a stationary system would be more promising, which would automatically conduct monitoring at individual points along the route of the train. Such story, in my opinion, is more realistic".

According to Sergei Goncharov, Deputy General Director for Technical Development - Chief Engineer of JSC First Freight Company [1]: “At the idea level, this is an interesting and useful project for operators, the main thing is that it be 
commercially justified. Everything will depend on the costs of production and operation of this system, as well as the level of quality of its work, which can be assessed during operational tests".

As we can see, the business is primarily interested in the cost of introducing this new product and how it will affect the cost structure of their enterprises.

\section{DEVELOPMENT OF THE OPERATING CONDITIONS MONITORING SYSTEM OF A CONTAINER WAGON}

\section{GENERAL SYSTEM DESCRIPTION}

As noted in the previous paragraphs, at present the concept of "Smart Wagon" is speculative and does not have clear creation criteria.

Therefore, we will develop a system that would fulfil one of the functions of the Smart Wagon concept, and specifically the detecting events function of non-compliance of the wagon operating conditions with the standards, which will allow us to document the facts of the incorrect handling of wagons in relation to time and GPS coordinates.
To do this, we need to connect and configure several components of the Internet of Things system, namely:

- A central server running under the Linux operating system with one of the widely used "Smart Home" open systems in the world;

- Modules of environmental sensors that use WIFI or ZigBee networks to transmit to the server the necessary environmental parameters inside and outside the wagon (temperature, atmospheric pressure, humidity, amount of particulate matter (PM10, PM2.5) and hazardous gases (formaldehyde, carbon monoxide, excess carbon dioxide);

- State sensors that track movements inside and outside the container platform (motion and presence sensors), possible drops and movement of the load (vibration sensors), as well as container opening sensors (reed sensors).

All measurements received from the sensors are stored in the server's memory, automatically linked to the time and geographic (GPS-mark) and transmitted outside via the Internet. This allows authorized users to track these parameters in any

PMS5003

\begin{tabular}{|c|c|c|c|c|c|}
\hline 111 & Содержание РM1.0 & $12 \mu \mathrm{g} / \mathrm{m} 3$ & 111 & Содержание РМ2.5 & $13 \mu \mathrm{g} / \mathrm{m} 3$ \\
\hline 111 & Содержание PM10 & $13 \mu \mathrm{g} / \mathrm{m} 3$ & $\equiv$ & Содержание пыли & $25.75 \mu \mathrm{g} / \mathrm{m} 3$ \\
\hline & Содержание Со & $1024.00 \mathrm{ppm}$ & $\mathrm{CO}_{2}$ & Содержание СО2 & $768.00 \mathrm{ppm}$ \\
\hline
\end{tabular}

Fig. 3. Information output from environmental sensors (author's picture)

График СO2 (Диоксид углерода)

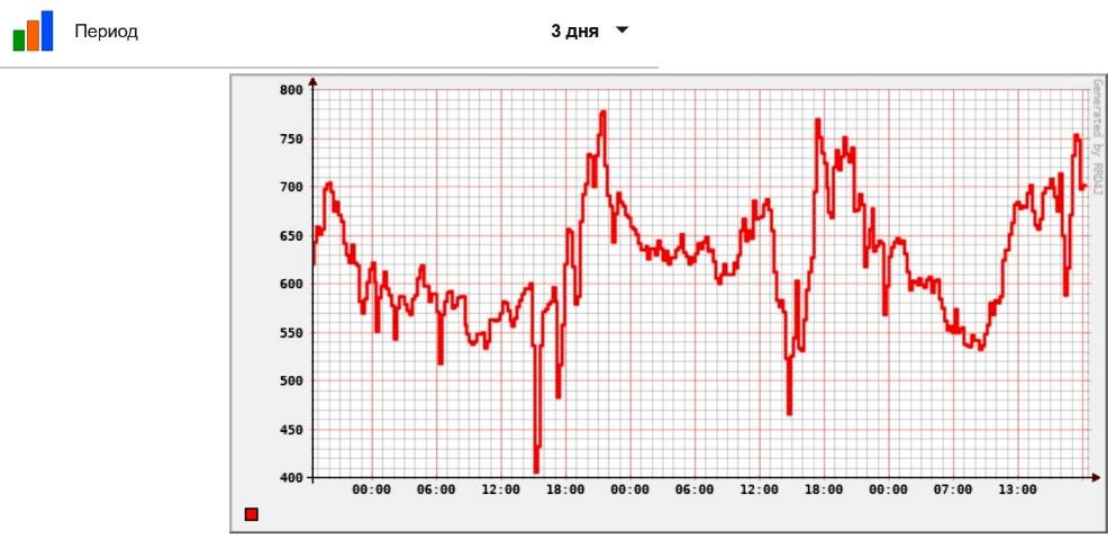

Fig. 4. Graph of changes in the amount of carbon dioxide in our system (author's picture) 


\begin{tabular}{|c|c|c|c|c|}
\hline 8 & Температура процессора & $43.3^{\circ}$ & Доступно памяти & $3247 \mathrm{MB}$ \\
\hline Th & Доступно памяти \% & $82.1 \%$ & Доступно на SD & 21585 MB \\
\hline प & Свободно на SD \% & $72.5 \%$ & Доступно SWAP & $100 \mathrm{MB}$ \\
\hline & Свободный SWAP \% & $100.0 \%$ & IP Aдpec & 192.168.6.164 \\
\hline & Мас адрес & $00: e 0: 4 c: 68: 50: 5 c$ & Данных отправленно & $24 \mathrm{MB}$ \\
\hline & Данных принято & $110 \mathrm{MB}$ & & \\
\hline
\end{tabular}

Fig. 5. Information on the status of the Smart Wagon system (author's drawing)

browser on any device with Internet access. The system developed by the author also allows the user to see graphs of changes in sensor data in real time for different time periods (8 hours, day, 3 days, month). Examples of the web interface of the system developed by the author are shown in Figures $3 \div 5$. Since the system is focused on use in the Russian Federation, the language of the system is Russian.

\section{THE MAIN COMPONENTS OF THE DEVELOPED SYSTEM}

Now we'll take a closer look at the main components of the developed system.

The server uses an x86 compatible Atomic Pi mini-computer (Fig. 6). This computer has the following specifications:

- SoC - Intel Atom x5-Z8350 quad core processor @ up to $1.92 \mathrm{GHz}$ with Intel HD graphics;

- System Memory-2GB DDR3L-1600;

- Storage - 16GB eMMC flash, slot for SD expansion up to $256 \mathrm{~GB}$;

- Video Output - HDMI port;

- Connectivity;

- Gigabit Ethernet via Realtek RTL8111G transceiver;

- Dual band $802.11 \mathrm{~b} / \mathrm{g} / \mathrm{n}$ WiFi 4 via RT5572 with IPX connectors on board;

- Bluetooth 4.0 via CSR8510;

- USB - USB 3.0 and USB 2.0 ports;

- Sensor -9-axis inertial navigation sensor with compass (BNO055);

- Expansion - JST style connectors and a 26-pin header for power \& GPIO;

- Debugging - TTL serial debug and expansion serial ports up to 3.6Mbps;

- Misc - Real time clock \& battery;

- Power Supply - 5V/4A recommended. 4-15 watts typ. power consumption;

- Dimensions - 130 × 100 × $50 \mathrm{~mm}$.

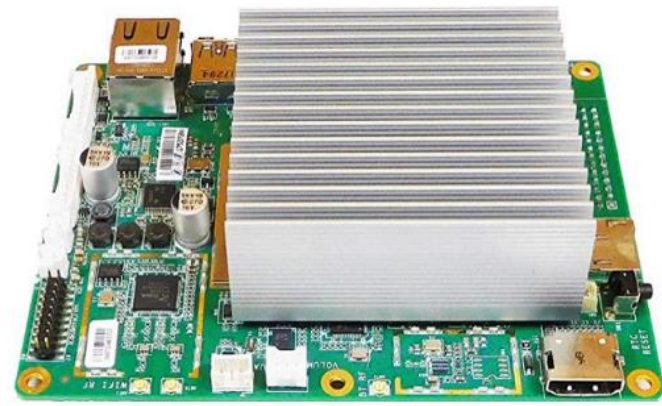

Fig. 6. System board of the Smart Wagon system developed by the author [5]

The case for this mini PC is printed on a Creality Ender 3 3D printer. This computer has built-in WIFI and Bluetooth interfaces, so the only thing you need to add is a USB U-Blox7 GPS / GLONASS controller (Fig. 7) to receive data from satellites and a ZigBee controller - CC2531 networks from Texas Instruments for communication with ZigBee sensors (Fig. 8).

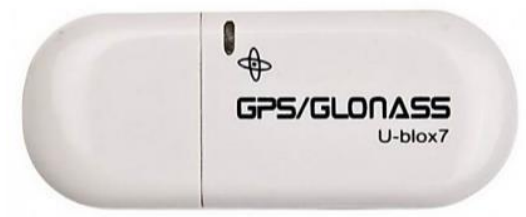

Fig. 7. GPS / GLONASS USB U-Blox7 controller [5]

A general view of the finished system is shown in Figure 9.

The used operating system is Ubuntu 18.04.3 LTS (Bionic Beaver). As an automation system, an open cross-platform openHAB system (Open Home Automation Bus), developed in Germany, is used. 
OpenHAB implements a single bus, i.e. allows you to combine all devices with different protocols into a single network, abstracting the user from each specific protocol. Thus, we can use the only contro tool (say, an application on a smartphone) and implement an arbitrarily complex logic of the relationship between devices.

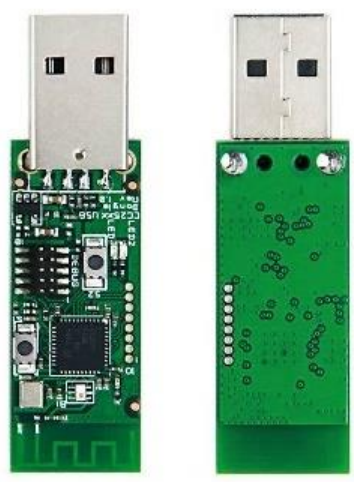

Fig. 8. Texas Instruments ZigBee Network Controller (CC2531) [5]
OpenHAB is a very flexible constructor. Based on OSGi technology, it allows you to configure each individual plugin (Binding) "on the fly" without rebooting the entire server [14].

The configuration of this system is carried out by editing several configuration files.

Things represent the physical layer of an openHAB system. From a configuration standpoint, things tell openHAB which physical entities (devices, web services, information sources, etc.) are to be managed by the system.

Things are connected to openHAB through bindings. In order to add a Thing to the system, we must first identify the appropriate binding which will provide the type of Thing you wish to add. For example, before adding a Thing for a Z-Wave device, the Z-Wave binding must first be installed.

Each Thing provides one or more Channels to access its functionality. These Channels can be linked to items. Items are used to control Things and consume their information. Ultimately, when Items are linked to Channels on a Thing, they become available to the various user interfaces and to the rules engine [15].

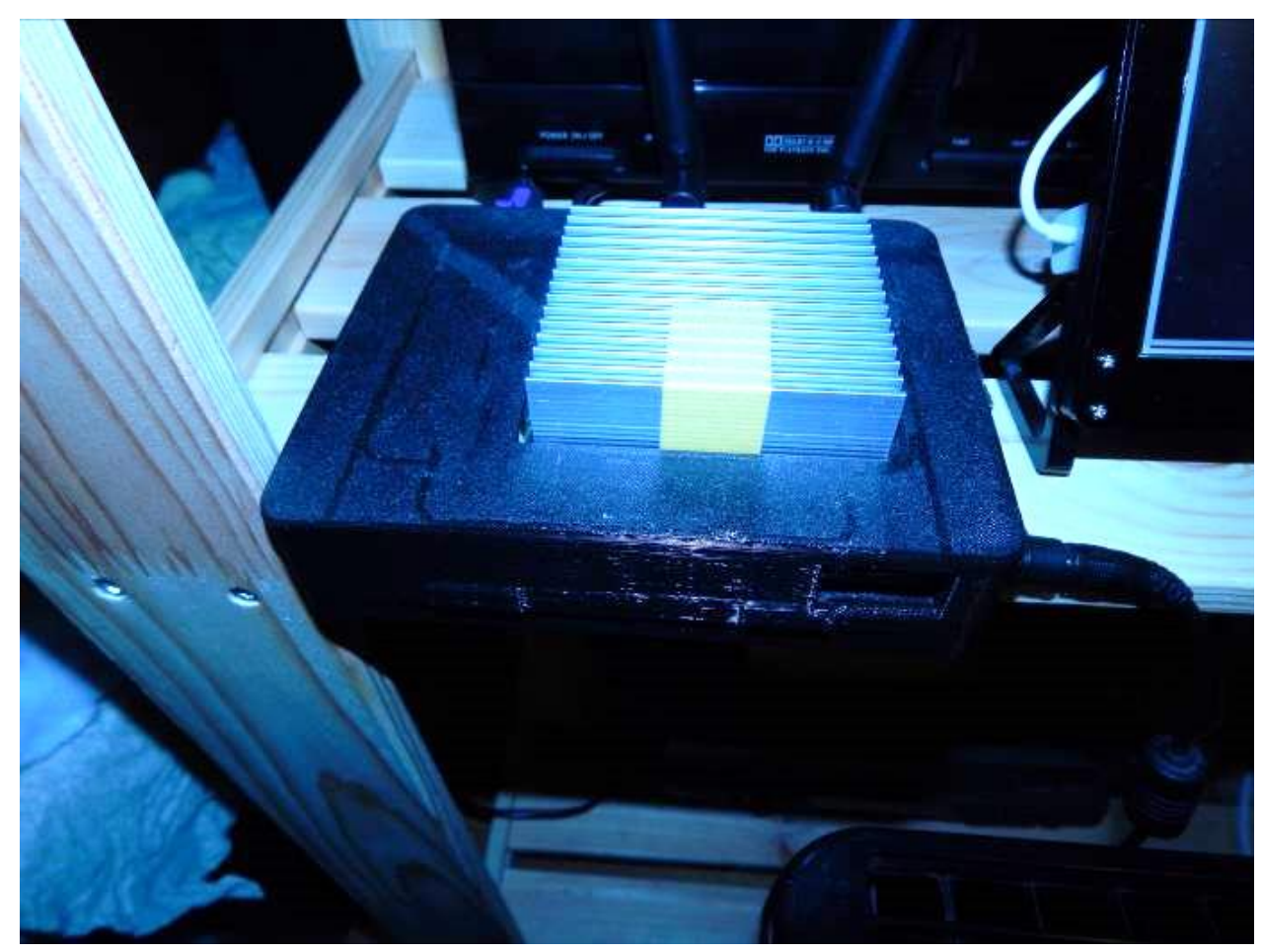

Fig. 9. Central server of the system "SW" developed by the author (author's picture) 


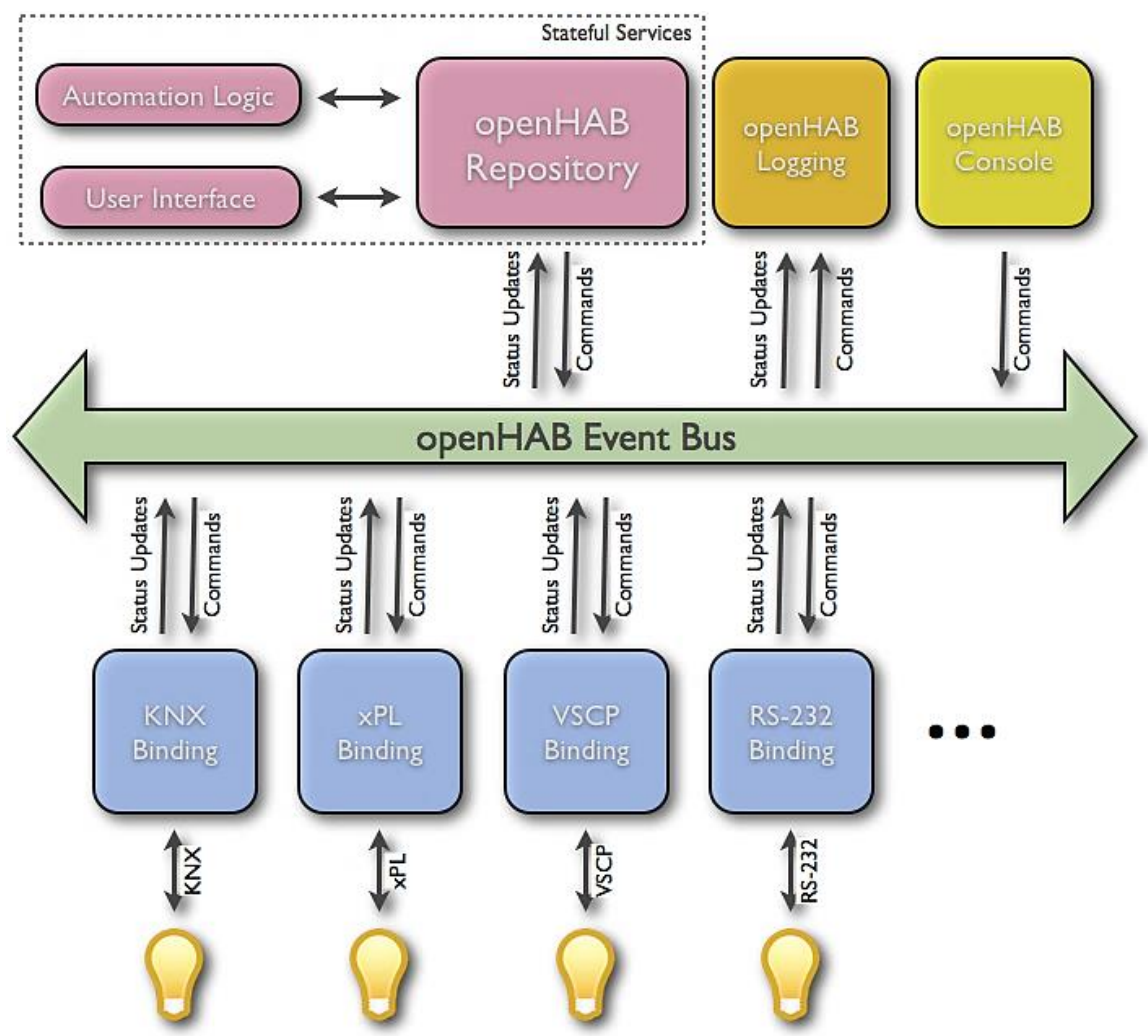

Fig. 10. General scheme of openHAB server operation [6]

Q Search

A Air Quality ONLINE

Air Quality

airquality:aqiihome

M Astro Moon Data ONLINE

Astro Moon Data

astro:moon:home

Astro Sun Data ONLINE

Astro Sun Data

Astrosuntome $\hat{\imath} \quad$ CLEAR

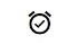

'ڤ”

(ิ)

Fig. 11. Examples of Things entities in the Smart Wagon system (author's picture)

OpenHAB has a strict separation between the physical world and the application, which is built around the notion of "Items" (also called the virtual layer).

Items represent functionality that is used by the application (mainly user interfaces or automation logic). Items have a state and are used through events.

\section{Sensor MOdUles Of the "SMARt WAgon" SYSTEM}

Each sensor in our system is a separate module that can operate both autonomously and as part of a common Smart Wagon system.

This allows us to make the modular system in order to increase fault tolerance and flexibly adapt to the needs of specific customers. 


\section{PM AIR QUALITY SENSOR}

PMS5003 is a kind of digital and universal particle concentration sensor, which can be used to obtain the number of suspended particles in the air, i.e. the concentration of particles, and output them in the form of digital interface. This sensor can be inserted into variable instruments related to the concentration of suspended particles in the air or other environmental improvement equipment's to provide correct concentration data in time.

Laser scattering principle is used for such sensor, i.e. produce scattering by using laser to radiate suspending particles in the air, then collect scattering light in a certain degree, and finally obtain the curve of scattering light change with time. In the end, equivalent particle diameter and the number of particles with different diameter per unit volume can be calculated by microprocessor based on MIE theory. The functional diagram of each part of sensor is shown in Figure 12 [7].

In the author's data module, the sensor is connected to the Wemos D1 mini board, which transfers data to external servers via Wi-Fi, and to the OLED screen module, which displays current data in real time.

The module operation diagram and final result is shown in Figures $13 \div 15$.

\section{FORMALDEHYDE SENSOR MODULE}

ZE08-CH2O is a general-purpose and miniaturization electrochemical formaldehyde detection module. It utilizes electrochemical principle to detect $\mathrm{CH} 2 \mathrm{O}$ in air which makes the module with high selectivity and stability.

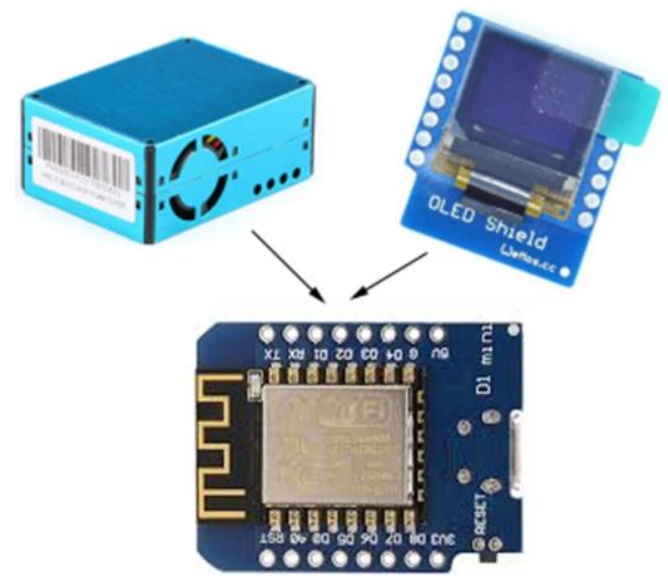

Fig. 13. The PMS module operation diagram (author's picture)

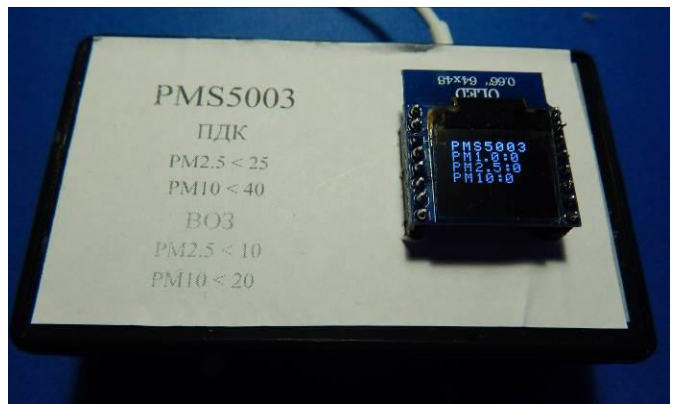

Fig. 14. Particle sensor module of the Smart Wagon system (author's picture)

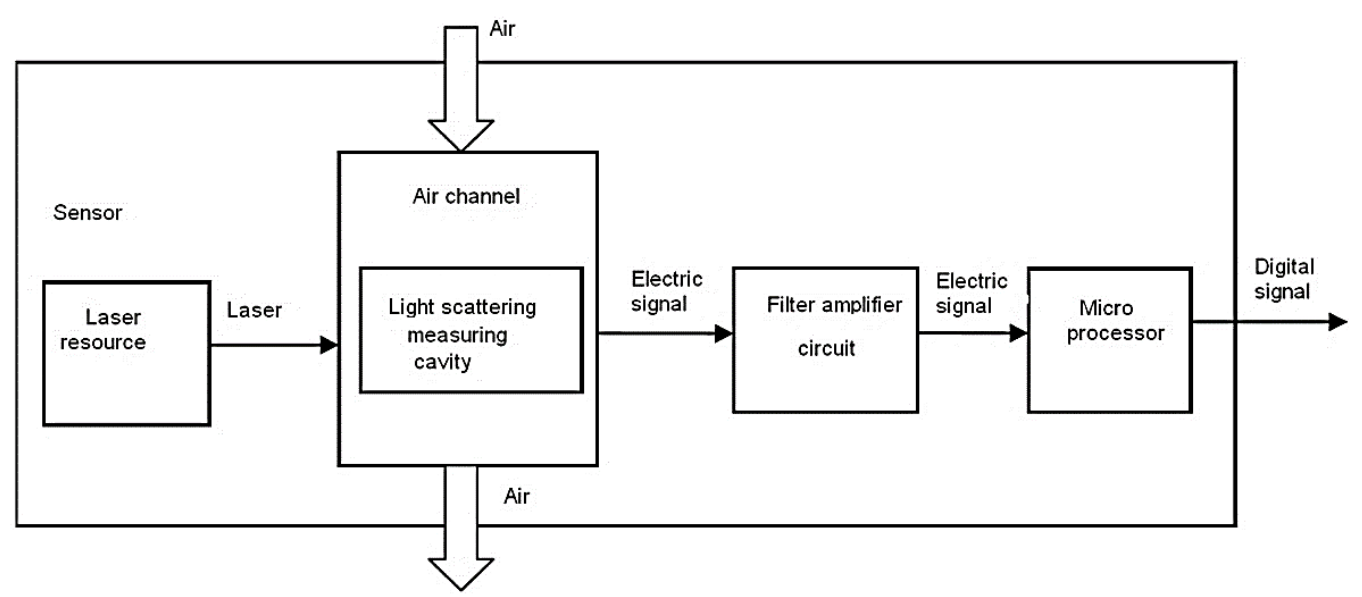

Fig. 12. Functional block diagram of PMS5003 sensor [7] 


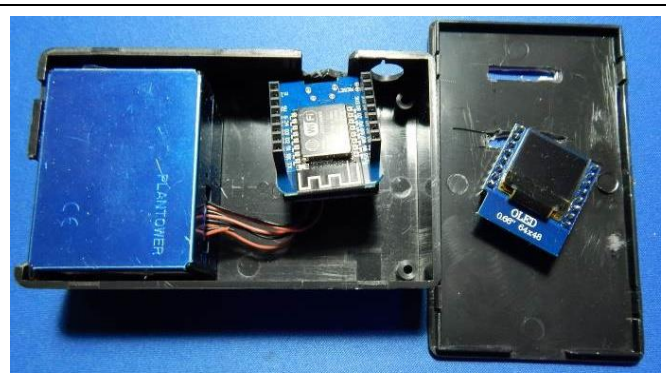

Fig. 15. Inside of particle sensor module of the Smart Wagon system (author's picture)
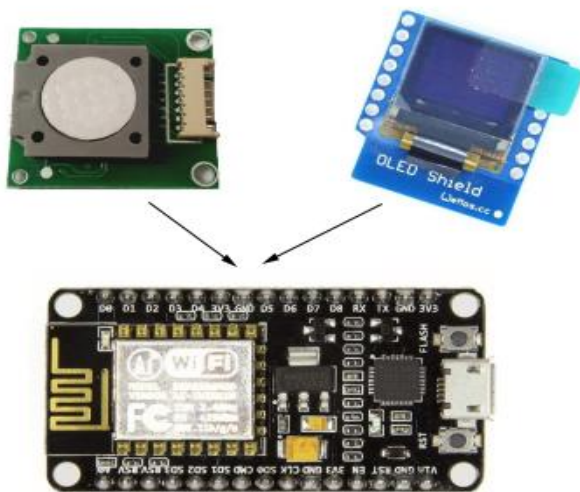

Fig. 16. The formaldehyde module operation diagram (author's picture)

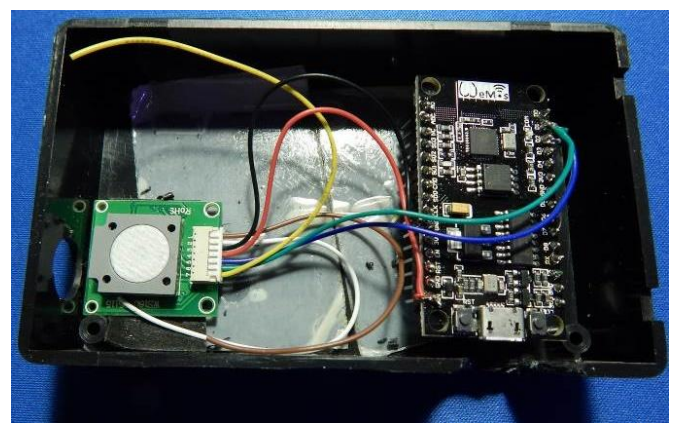

Fig. 17. Inside of formaldehyde sensor module of the Smart Wagon system (author's picture)

It is built-in temperature sensor to make temperature compensation. It has the digital output and analog voltage output at the same time. It is a combination of mature electrochemical detection principle and sophisticated circuit design [8].

In the author's data module, the sensor is connected to the Node MCU board, which transfers data to external servers via $\mathrm{Wi}-\mathrm{Fi}$, and to the OLED screen module, which displays current data in real time.
The module operation diagram and final result is shown in Figures $16 \div 17$.

\section{RADIATION SENSOR MODULE}

In order to measure the level of gamma radiation within our freight wagon, a modular system based on a M4011 sensor is used. This sensor has the following characteristics.

M4011 Geiger Tube Specification [9]:

Tin oxide Cathode, Coaxial cylindrical thin shell structure (Wall density $50 \pm 10 \mathrm{cg} / \mathrm{cm} 2$ )

Application of pulse type halogen tube:

1) Application temperature: $-40^{\circ} \mathrm{C} \sim 55^{\circ} \mathrm{C}$;

2) Could be used for: $\gamma$ Ray $20 \mathrm{mR} / \mathrm{h} \sim 120 \mathrm{mR} / \mathrm{h}$ and $\beta$ Ray in range 100 1800. Changing Index/minutes.CM2 soft $\beta$ Ray. Both beta and gamma radiation detection;

3) Working Voltage: $380-450 \mathrm{~V}$;

4) Working Current: 0,015-0,02 mA;

5) Sensitivity to Gamma Radiation: $0.1 \mathrm{MeV}$;

6) Length: $88 \mathrm{~mm}$;

7) Diameter: $10 \mathrm{~mm}$;

8) start voltage: $<350 \mathrm{~V}$;

9) suggested working voltage : 380V; Maximum working voltage: $550 \mathrm{~V}$;

10) The minimum length of Plateau: $80 \mathrm{~V}$

11) The largest plateau slope: $10 \% / 80 \mathrm{~V}$;

12) Own Background: 25 pulse/minutes.

In the author's data module, the sensor is connected to the Arduino Pro Mini board, which transfers data via serial interface to Wemos D1 mini board, which transfers data to external servers via Wi-Fi.

The module operation diagram and final result is shown in Figures $18 \div 20$.

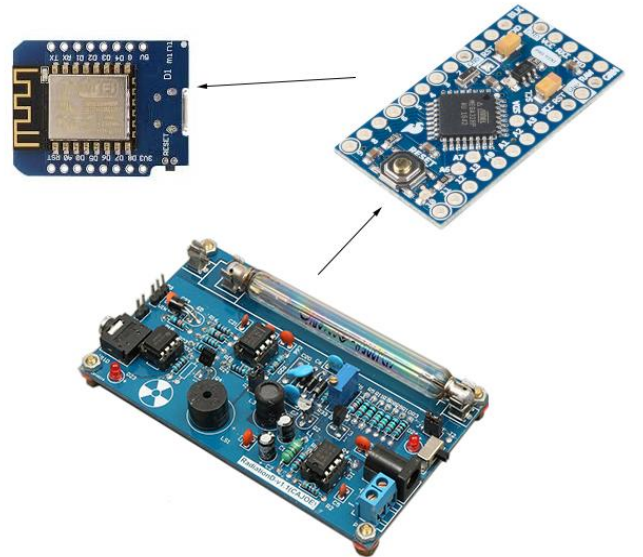

Fig. 18. The Radiation module operation diagram (author's picture) 


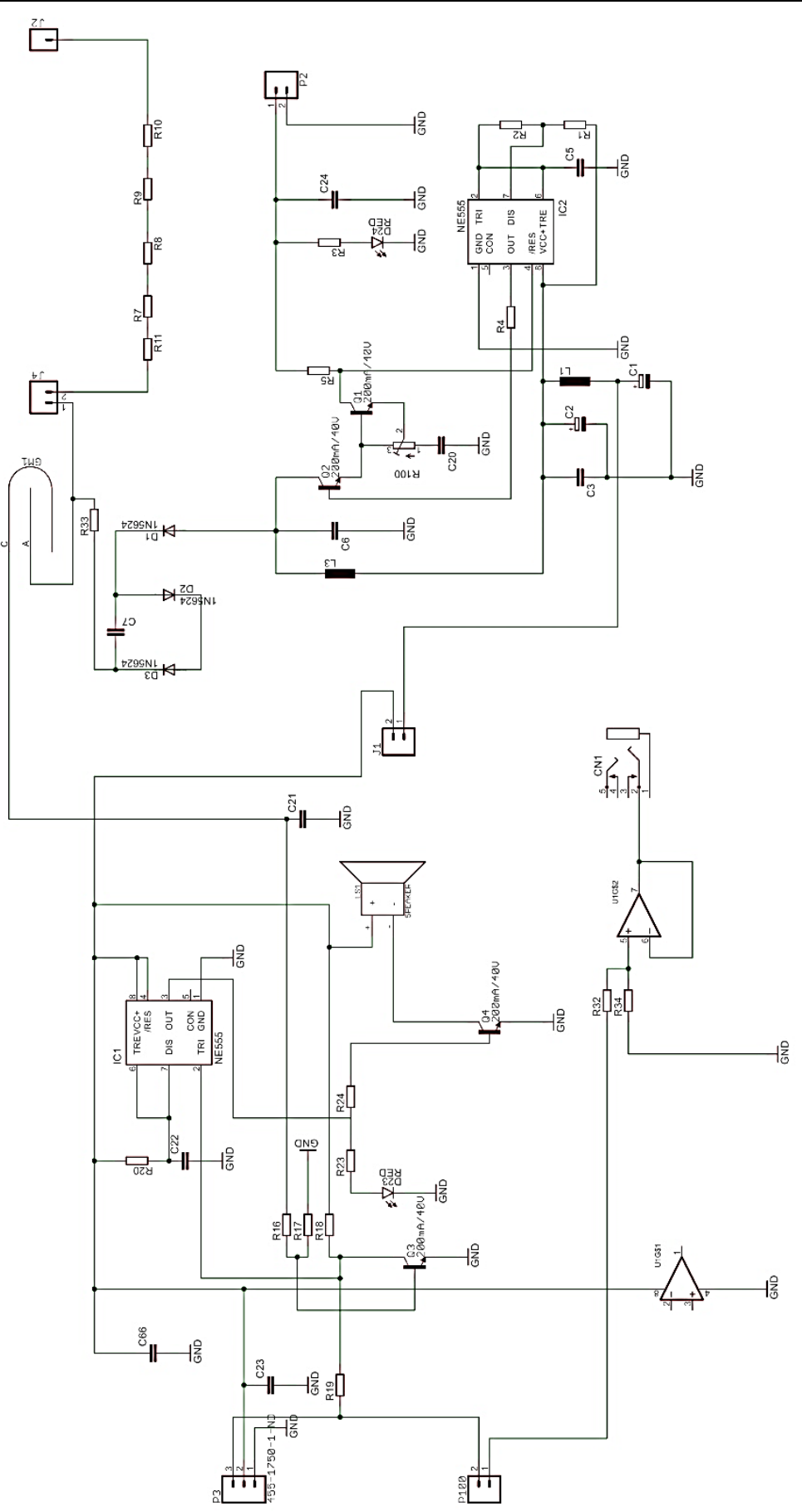

Fig. 19. Geiger Counter Diagram [10] 


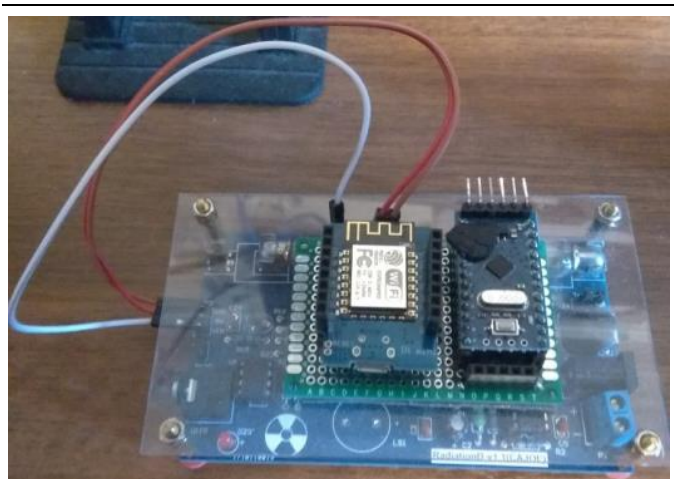

Fig. 20. Radiation module of the Smart Wagon system (author's picture)

As a result, the system displays radiation data in the form of counting the number of measurements of radioactive particles per minute (Counts per minute) and the background level in millisieverts. Based on the measurement results, charts are built for 8 hours, a day, three days, a week, and so on. The general view of data output (in Russian) is shown in the figure 21 .

CO AND CO2 SENSOR MODULE

$\mathrm{CO}$ and $\mathrm{CO} 2$ sensor module is used to measure the concentration of carbon monoxide (CO) and carbon dioxide (CO2) within our wagon.

Two types of sensors are used for this:

- Carbon monoxide (CO) sensor;

- Carbon dioxide (CO2) sensor MH-Z19B.

In the author's data module, the sensors are connected to the Wemos D1 mini, which transfers data to external servers via Wi-Fi (Fig. 22).

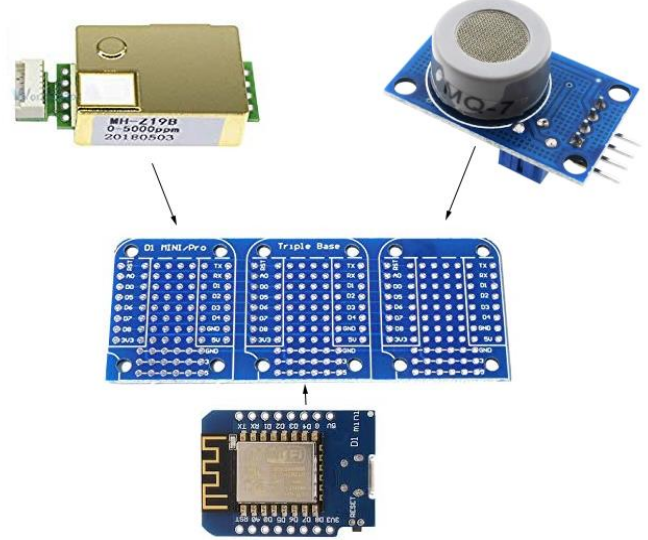

Fig. 22. The $\mathrm{CO}$ and $\mathrm{CO} 2$ module operation diagram (author's picture)

\begin{tabular}{|c|c|c|c|}
\hline (1) Уровень радиации в СРМ & $12 \mathrm{cpm}$ & Уровень радиации в $\mu \mathrm{Sv} / \mathrm{h}$ & $0.08 \mu \mathrm{Sv} / \mathrm{h}$ \\
\hline 1. Уровень радиации в $\mu \mathrm{Sv} / \mathrm{h}$ & 0.08 & & \\
\hline
\end{tabular}

График радиации

Период

3 дня -

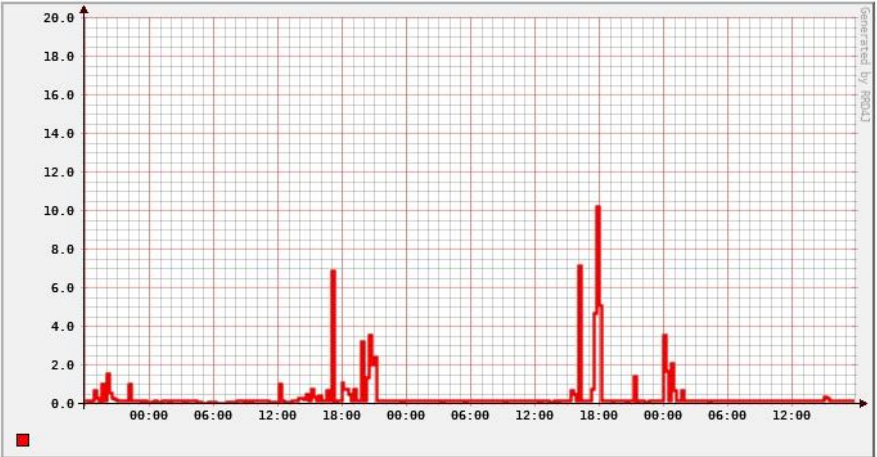

Fig. 21. The general view of radiation data output (in Russian) (author's picture) 
Concept «Smart freight wagon»

\begin{tabular}{|c|c|c|c|c|}
\hline Target Gas & Formula & $\begin{array}{c}\text { Measuring } \\
\text { Range }\end{array}$ & Accuracy & Remark \\
\hline \multirow[t]{2}{*}{ Carbon Dioxide } & \multirow{2}{*}{$\mathrm{CO}_{2}$} & $0 \sim 2000 \mathrm{ppm}$ & \multirow{2}{*}{$\begin{array}{l} \pm(50 \mathrm{ppm}+3 \% \\
\text { reading value })\end{array}$} & $\begin{array}{l}\text { Temperature } \\
\text { compensation }\end{array}$ \\
\hline & & $0 \sim 5000 \mathrm{ppm}$ & & $\begin{array}{l}\text { Temperature } \\
\text { compensation }\end{array}$ \\
\hline
\end{tabular}

Fig. 23. Measuring Range and Accuracy of MH-Z19B [12]

Sensitive material of $\mathrm{MQ}-7$ gas sensor is $\mathrm{SnO} 2$, which with lower conductivity in clean air. It make detection by method of cycle high and low temperature, and detect $\mathrm{CO}$ at low temperature (heated by $1.5 \mathrm{~V}$ ). The sensor's conductivity gets higher along with the $\mathrm{CO}$ gas concentration rising. At high temperature (heated by 5.0V), it cleans the other gases adsorbed at low temperature. Users can convert the change of conductivityto correspond output signal of gas concentration through a simple circuit [11].

It has good sensitivity to carbon monoxide in wide range, and has advantages such as long lifespan, low cost and simple drive circuit.

$\mathrm{MH}-\mathrm{Z19B}$ infrared gas module is a common type, small size sensor, using nondispersiveinfrared (NDIR) principle to detect the existence of $\mathrm{CO} 2$ in the air, with good selectivity, non-oxygendependent and long life. Built-in temperature compensation and it has UART output and PWMoutput. It is developed by the tight integration of mature infrared absorbing gas detection technology, precision optical circuit design and superior circuit design [12].

$A B C$ logic function refers to that sensor itself do zero point judgment and automatic calibration procedure intelligently after a continuous operation period. The automatic calibration cycle is every 24 hours after powered on. The zero point of automatic calibration is $400 \mathrm{ppm}$.

The final result module is shown in Figures $18 \div 20$.

\section{DUST SENSOR MODULE}

Dust sensor module is used to measure the concentration of dust within our wagon. It uses GP2Y1010AUOF sensor.

Sharp GP2Y1010AUOF is a dust sensor by optical sensing system. An infrared emitting diode (IRED) and a phototransistor are diagonally arranged into this device. It detects the reflected light of dust in air.

Especially, it is effective to detect very fine particle like the cigarette smoke. In addition, it can distinguish smoke from house dust by pulse pattern of output voltage [13].

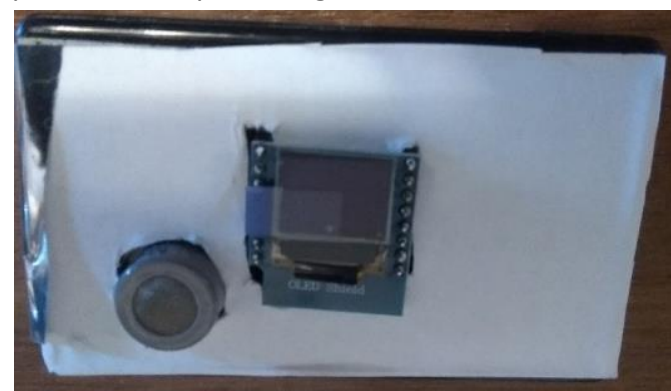

Fig. 24. $\mathrm{CO}$ and $\mathrm{CO} 2$ module of the Smart Wagon system (author's picture)

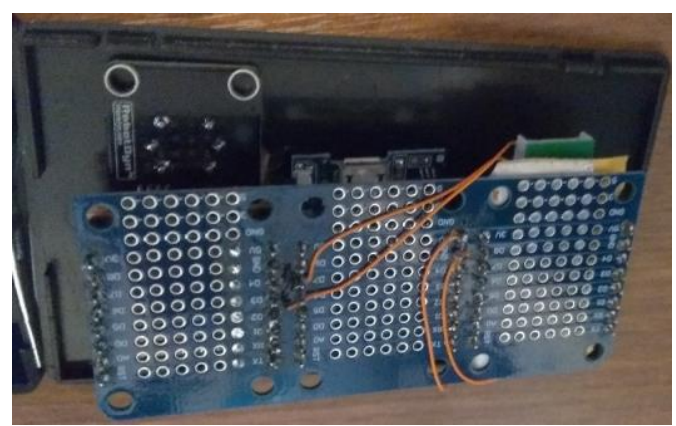

Fig. 25. Inside of $\mathrm{CO}$ and $\mathrm{CO} 2$ sensor module of the Smart Wagon system (author's picture)

In the author's data module, the sensors are connected to the Wemos D1 mini, which transfers data to external servers via $\mathrm{Wi}-\mathrm{Fi}$. 


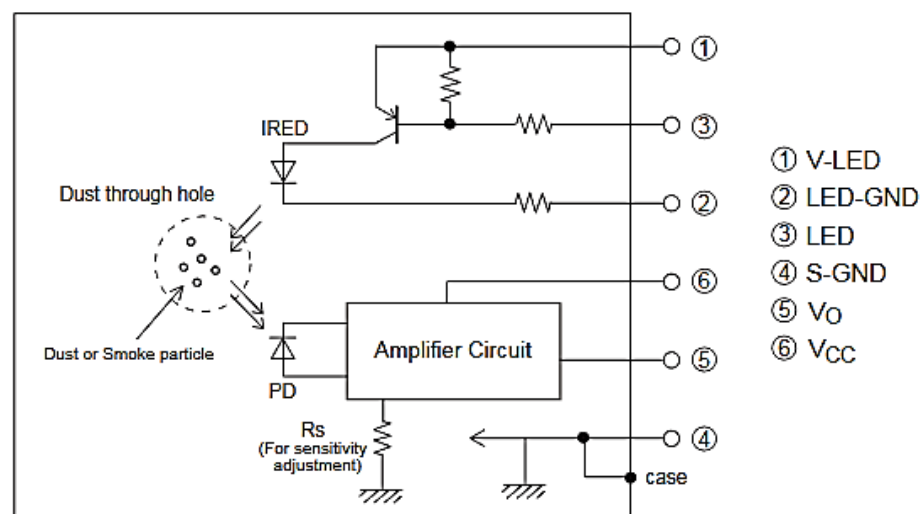

Fig. 26. Sharp GP2Y1010AUOF Diagram [13]

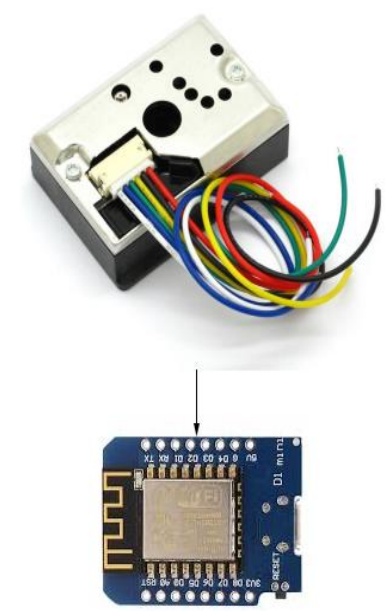

Fig. 27. Dust module operation diagram (author's picture) The final result module is shown in Figures $28 \div 29$.

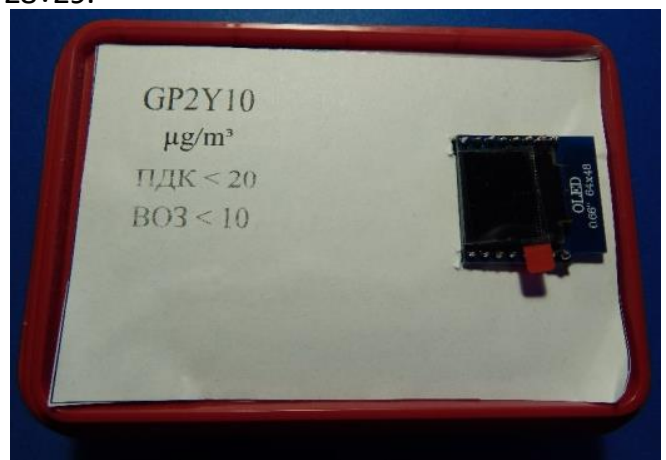

Fig. 28. Dust sensor module of the Smart Wagon system (author's picture)

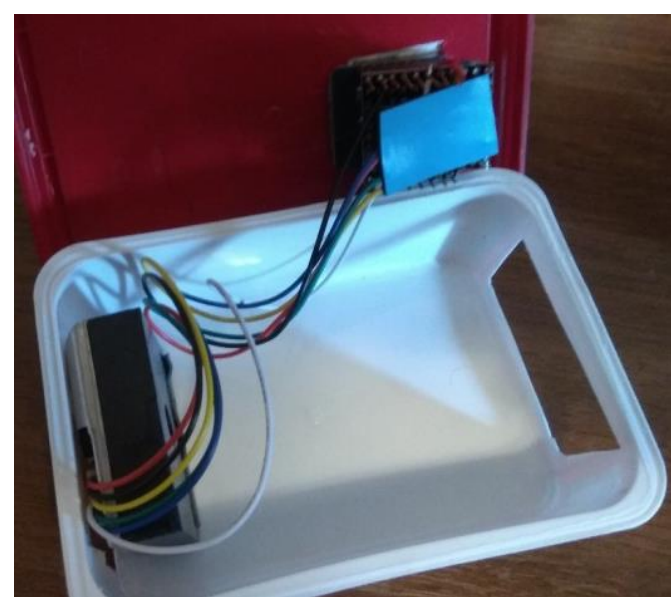

Fig. 29. Inside of dust sensor module of the Smart Wagon system (author's picture)

The general result of the output of data on the state of air in our system (in Russian) is presented in the figure 30. Based on the measurement results, charts are built for 8 hours, a day, three days, a week, and so on.

\section{CONCLUSIONS}

In conclusion, it should be noted that the Smart Wagon system is still in the stage of very early planning in Russia. So far, only the basic wishes for the system are clear and the criteria for its implementation are not clearly defined. This allows the authors and other researchers in the Russian Federation to propose various approaches to the creation of this system, which will ultimately make the finished system more flexible and prepared for the requirements of the modern transport market. 


\begin{tabular}{|c|c|c|c|c|c|}
\hline 111 & Содержание РM1.0 & $5 \mu \mathrm{g} / \mathrm{m} 3$ & 111 & Содержание PM2.5 & $9 \mu \mathrm{g} / \mathrm{m} 3$ \\
\hline 111 & Содержание РM10 & $9 \mu \mathrm{g} / \mathrm{m} 3$ & $\equiv$ & Содержание пыли & $23.55 \mu \mathrm{g} / \mathrm{m} 3$ \\
\hline & Содержание СО & $1024.00 \mathrm{ppm}$ & $\mathrm{CO}_{2}$ & Содержание СO2 & $752.00 \mathrm{ppm}$ \\
\hline & Содержание СН2O & $30 \mathrm{ppm}$ & & & \\
\hline
\end{tabular}

\section{График CO2 (Диоксид углерода)}

Период

3 дня -

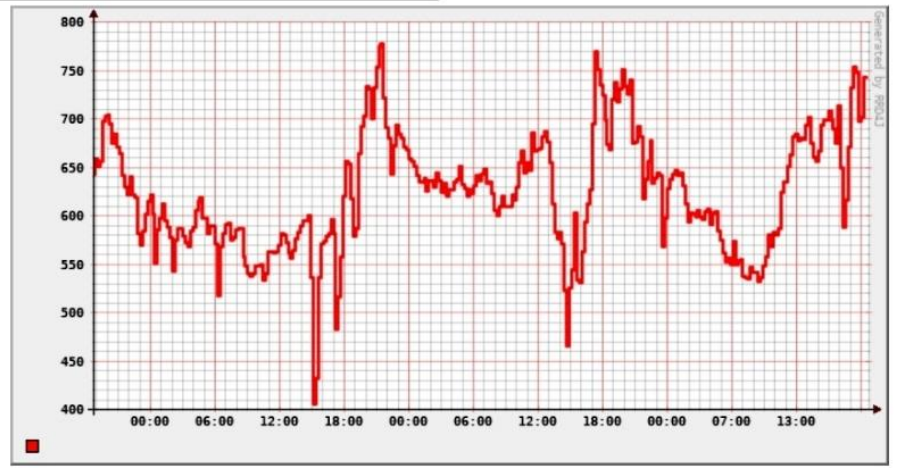

Fig. 30. The general view of air quality data output (in Russian) (author's picture)

So, in this article the author's intelligent tracking parameters container system is described. This system works on the basis of sensors from leading manufacturers (Bosch, Sharp and others) and provides a sufficient level of stability and scalability.

For data transmission technologies cellular and wifi networks are used. As the frontend of the shell, an open source openHAB system is used.

All this allows to further flexibly adapt the system to the needs of end customers and, if necessary, include new and improved components in its composition.

The authors would like the operators of the railway infrastructure, based on the proposals of various authors, be able to create an effective system for the analysis of container traffic data, which would bring railway traffic in Eurasia to a new level.

\section{KONCEPCJA «INTELIGENTNY WAGON TOWAROWY»}

W niniejszym artykule omówiono perspektywę wdrożenia inteligentnego wagonu towarowego na rosyjskich kolejach. Przedstawiono opracowywaną w Rosji koncepcję systemu monitorowania warunków eksploatacji taboru kolejowego i przekazywania danych telemetrycznych odnoszących się do stanu infrastruktury pod nazwą projektową "Inteligentny wagon towarowy". Ponadto, autorzy proponują nowatorskie podejście - udoskonalenie omawianego systemu w oparciu o model inteligentnego systemu openHAB, który pomaga stworzyć system modułowy celem zwiększenia tolerancji na uszkodzenia i tym samym pozwala na elastyczne dostosowywanie się do potrzeb określonych klientów.

Słowa kluczowe: «Inteligentna lokomotywa», «Inteligentny wagon towarowy», rosyjskie koleje

\section{BIBLIOGRAPHY}

[1] "Skolkovo will create a smart car monitoring system", Gudok, Moscow 2017

[2] Orlova A. (2018) "Smart Wagon", Zheleznodorozhnik magazine, Moscow

[3] The official website of the Scientific and Technical Center "Ingetrans", https://ingetrans.ru (access date: 21/10/2019)

[4] Information Agency "RZD-Partner.ru", Moscow, 2018, https://www.rzd-partner.ru/zhd-transport/news/nasozdanie-umnogo-vagona-potrebuetsya-ne-menee-tryekhlet/ (access date: $21 / 10 / 2019$ )

[5] Amazon.com, http://www.amazon.com (access date: 21/10/2019) 
[6] OpenHAB - become a programmer of your own home https://habr.com/ru/post/232969/ (access date: 21/10/2019)

[7] PMS5003 series data manual, https://www.aqmd.gov/ docs/default-source/aq-spec/resources-page/plantower-pms 5003-manual_v2-3.pdf (access date: 21/10/2019)

[8] Electrochemical $\mathrm{CH}_{2} \mathrm{O}$ Detection Module User's Manual, https://www.winsen-sensor.com/d/files/PDF/Gas\%20Sensor \%20Module/Formaldehyde\%20Detection\%20Module/ZEO 8-CH2O\%20V1.0.pdf (access date: 21/10/2019)

[9] M4011 Geiger Tube Specification, https://github.com/ Sensorslot/Geiger-Counter-RadiationD-v1.1-CAJOE-/blob/ master/M4011\%20Geiger\%20Tube\%20Specification.pdf (access date: 21/10/2019)

[10] Geiger Counter Diagram, https://github.com/Sensorslot/ Geiger-Counter-RadiationD-v1.1-CAJOE-/blob/master/Geiger \%20Counter\%20Diagram.pdf (access date: 21/10/2019)

[11] MQ-7 Semiconductor Sensor for Carbon Monoxide, https://cdn.sparkfun.com/datasheets/Sensors/Biometric/ MQ-7\%20Ver1.3\%20-\%20Manual.pdf (access date: 21/10/2019)
[12] Intelligent Infrared $\mathrm{CO}_{2}$ Module, https://www.winsen-sensor .com/d/files/infrared-gas-sensor/mh-z19b-co2-ver1_0.pdf (access date: $21 / 10 / 2019$ )

[13] Compact Optical Dust Sensor GP2Y1010AUOF datasheet https://www.sparkfun.com/datasheets/Sensors/gp2y1010 au e.pdf (access date: $21 / 10 / 2019$ )

[14] Hosek J., Masek P., Kovac D., Ries M., Kröpfl F. (2014). "Universal smart energy communication platform", International Conference on Intelligent Green Building and Smart Grid (IGBSG), 23-25 April 2014, Taipei, Taiwan, IEEE, doi: 10.1109/IGBSG.2014.6835232, pp. 1-4 (access date: 21/10/2019)

[15] Шматков В.Н., Бонковски П., Медведев Д.С., Корзухин С.В., Голендухин Д.В., Спыну С.Ф., Муромцев Д.И. (2019). "Взаимодействие с устройствами интернета вещей с использованием голосового интерфейса". Научнотехнический вестник информационных технологий, механики и оптики, doi: 10.17586/2226-1494-2019-19-4714-721, Vol. 19, No. 4, pp 714-721 